\title{
Students' Mathematical Communication Skills in Terms of Concrete and Abstract Sequential Thinking Styles
}

\author{
Lintang Fitra Utami ${ }^{\text {* }}$, Ikrar Pramudya ${ }^{2}$, Isnandar Slamet ${ }^{3}$ \\ 1,2,3 Universitas Sebelas Maret, Indonesia
}

\author{
Article Info \\ Submitted : 11-11-2020 \\ Revised : 12-12-2020 \\ Accepted : 14-12-2020 \\ Published : $17-12-2020$
}

*Correspondence:

lintangfitrautami87@gmail.com

\begin{abstract}
This study aimed to analyze and describe the eleventh-grade senior high school students' mathematical communication skills on linear program material in terms of concrete and abstract sequential thinking styles. This study employed a qualitative descriptive approach with the case study method. The sampling technique used was the purposive sampling technique. The mathematical communication skills test and thinking style questionnaires were employed as the data collecting technique. The analysis revealed that subjects in the AS category could make generalizations based on good reasoning in the written text aspect. On the other hand, subjects in the CS category were having a hard time constructing abstract assumptions. In the drawing aspect, subjects in the AS category showed good theories and concept understanding. In contrast, subjects in the CS category were only able to apply some of the information to draw graphs. In mathematical expressions, subjects in the AS category could process the information implied by the problem to make mathematical models correctly. Meanwhile, subjects in the CS category needed additional information or direction to understand the information to avoid mistakes.
\end{abstract}

Keywords: Concrete Sequential; Mathematical Communication Skills; Sequential Abstract.

\section{Introduction}

Education plays a vital role in equipping individuals to face global challenges or competition. Education in the $21^{\text {st }}$-century requires students to have four competencies called $4 \mathrm{C}$, namely critical thinking, collaboration, creativity, and communication. Fundamentally, learning is a process using communication skills. Communication skills are critical in learning mathematics because it enables the students to express ideas and reflect their mathematics understanding to others (Veva, Usodo, \& Pramesti, 2018; Zahri, Budayasa, \& Lukito, 2019).

National Council of Teachers of Mathematics (Oktari \& Haji, 2018) states that mathematical communication skills are students' skills to use and communicate mathematics (mathematical language). According to Elliott and Kenney (Ratnaningsih, Hermanto, \& Kurniati, 2019), mathematical communication skills consist of three aspects: writing, drawing, and mathematical expression. Writing skills are the ability to convey written mathematical ideas using one's language appropriately. The drawing skills are the ability to communicate mathematical ideas in pictures, graphs, tables, and diagrams. Mathematical expression skills can convey mathematical ideas or ideas in real situations into language, symbols, or mathematical models.

Based on the results of observations on July 21, 2020, it was found that many students had difficulty in solving problems. They were asked to come up with ideas on how to make proper plans to solve problems. However, many students made mistakes. The mistakes showed that their communication skills were lacking. Students with good communication skills can express ideas 
using good language, describe problems in the form of pictures or vice versa appropriately, and do calculations correctly. Therefore, there was a need for further research on students' mathematical communication skills.

Based on previous research by Rahmawati, it was found that the level of communication skills of vocational high school students was poor based on two indicators: stating daily events using mathematical language and connecting the graph with mathematical ideas (N. S. Rahmawati, Bernard, \& Akbar, 2019). Sari's research results showed that students' mathematical communication skills were poor. The percentages of achievement of students' mathematics communication indicators are as follows: 1) expressing mathematical situations, ideas, and correlations into pictures, graphs, or algebraic expressions (35\%), 2) converting everyday experiences into mathematical language, symbols, or models (35\%), and 3) linking pictures or diagrams to mathematical ideas $(53.3 \%)$. The poor skills might be caused by students' inability to systematically conveying or writing their mathematical ideas (Sari, Kusnandi, \& Suhendra, 2017). Azizah showed that the students' communication skills have not yet reached every mathematical communication skills indicators (Azizah \& Maulana, 2018).

Internal and external factors can influence students' mathematical communication skills. Internal factors come from within students, such as learning styles, thinking styles, motivation, and learning interest. External factors come from outside the student, such as facilities and infrastructure, environment, teachers, curriculum, and teaching methods (Safa'udin, Budiyono, $\&$ Saputro, 2015). Every student has a level of ability to understand and master different learning materials. These differences affect how students communicate and think (Rahmy, Usodo, \& Slamet, 2019). According to Mayer (Djadir \& Sulfianti, 2018), thinking is an abstract cognitive activity in a person's mind and mental but can be concluded based on problems.

Thinking style is one of the factors that can influence students' communication. Thinking style is a branch of psychology that examines the way individuals use their abilities or skills to overcome the problems they face (Khambali, Rasyid, \& Rafli, 2019). Thinking style is known as brain domination which can make a person chooses a way or strategy to solve a problem and adjust it according to his abilities (AlGhraibeh, 2015). Based on previous research, thinking styles affect students' mathematical connection abilities (Muflihah, Ratnaningsih, \& Apiati, 2019), misconceptions and procedures (Khair, Subanji, \& Muksar, 2018; Lenterawati, Pramudya, \& Kuswardi, 2018), learning outcomes (Sumandya, 2018), mathematical creative thinking skills (Alifiyah \& Kurniasari, 2019; Munahefi, Kartono, Waluya, \& Dwijanto, 2020), and critical thinking skills (Firdaus, Nisa, \& Nadhifah, 2019).

Anthony Gregorc divides thinking styles into four combinations, namely concrete sequential (CS), abstract sequential (AS), concrete random (CR), and abstract random (AR). Students in the sequential categories tend to have left-brain dominance, while students in the random categories tend to have right-brain dominance. According to Deporter and Hernacki, concrete sequential thinkers hold onto reality and process information in an orderly, linear, and sequential way. Concrete sequential thinkers always use physical senses such as sight, hearing, touch, taste, and smell to see reality. Concrete sequential thinkers love specific directions and procedures and hard to work the abstract concepts and imagination when there are no clear boundaries, certainties, and irregularities (Deporter \& Hernacki, 2015). Abstract sequential thinking is a learning style with high reasoning abilities and tends to be critical and analytical because it has a strong imagination. They generally capture lessons or information abstractly and do not need concrete demonstrations (Masruroh, 2018). 
Students' different thinking styles affect their ideas communication method. Therefore, this study described the eleventh-grade science senior high school students based on concrete sequential and abstract sequential thinking styles. The material chosen in this study was the linear program. This study was different from the previous ones because it analyzed and described every aspect of mathematical communication skills from concrete and abstract sequential thinking styles.

\section{The Research Methods}

This study employed the qualitative-descriptive approach with a case study research method. Case study research aims to understand one phenomenon by ignoring other phenomena deeply. The phenomenon in this was students' mathematical communication skills. Bogdan and Taylor (Moleong, 2014) define qualitative research as a research procedure that produces descriptive data in the form of written or spoken words from people. It also observed behavior from the emerging phenomena. Research using this method aims to describe the conditions during the research. The sampling technique used was purposive sampling technique to select ten out of thirty-two eleventh-grade science students at a senior high school in Tulang Bawang Barat Regency. The subjects selected in this study were based on several criteria: 1) students who have received Linear Program material, 2) students with concrete sequential and abstract sequential thinking styles, 3) mathematic teachers' recommendations, and 4) students' ability to express written and oral ideas. The instruments used were a test of mathematical communication skills and a questionnaire for students' thinking styles. The flowchart of this study is displayed in Figure 1.

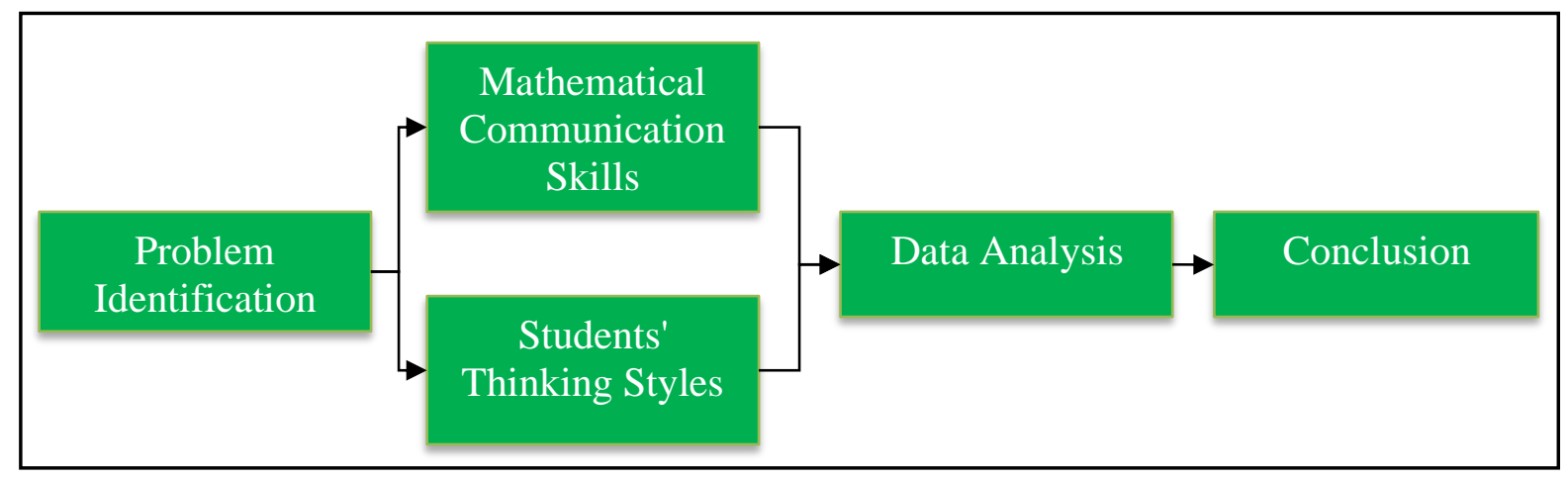

Figure 1. Research Flowchart

The questionnaire for thinking styles was a modification result developed by John Parks Le Tiller. The questionnaire had been validated by three experts in the field of psychology. The indicators of mathematical communication skills can be seen in Table 1 below.

Table 1. Mathematical Communication Skills Indicators

\begin{tabular}{cl}
\hline Aspects & \multicolumn{1}{c}{ Indicators } \\
\hline Written Text & $\begin{array}{l}\text { Declaring and explaining a situation, a picture, or a model in the } \\
\text { form of mathematical ideas using their language. }\end{array}$ \\
\hline Drawing & $\begin{array}{l}\text { Stating a situation or idea mathematically in the form of images, } \\
\text { graphics, tables, or diagrams. }\end{array}$ \\
\hline Mathematical Expressions & $\begin{array}{l}\text { Stating Mathematical situations or ideas into symbols or } \\
\text { mathematical models and then solving them. }\end{array}$ \\
\hline
\end{tabular}


The rubric to determine mathematical communication skills was a modified version of the High School Math Communication GRC Rubric, Maryland Math Communication Rubric, Quasar General Rubric, and Maine Holistic Rubric for Mathematics. The rubrics are shown in Table 2.

Table 2. Rubric for Assessing Mathematical Communication Skills

\begin{tabular}{|c|c|c|c|}
\hline \multirow{2}{*}{ Level } & \multicolumn{3}{|c|}{ Aspect } \\
\hline & Written Text & Drawing & Mathemamtical Expressions \\
\hline $\begin{array}{c}0 \\
\text { Poor }\end{array}$ & No answers & No answers & No answers \\
\hline $\begin{array}{c}1 \\
\text { Low }\end{array}$ & $\begin{array}{l}\text { Students write } \\
\text { explanations using their } \\
\text { language, but the } \\
\text { explanations given are } \\
\text { difficult to understand, } \\
\text { incorrect, and unclear. }\end{array}$ & $\begin{array}{c}\text { Students can draw pictures, } \\
\text { diagrams, graphs, or tables } \\
\text { incorrectly. }\end{array}$ & $\begin{array}{l}\text { Students cannot make } \\
\text { mathematical models and } \\
\text { solve mathematical language } \\
\text { problems (symbols, terms, } \\
\text { signs, or formulas). }\end{array}$ \\
\hline $\begin{array}{c}2 \\
\text { Moderate }\end{array}$ & $\begin{array}{c}\text { Students write } \\
\text { descriptions using their } \\
\text { language. However, the } \\
\text { explanation is only } \\
\text { partially correct, } \\
\text { incomplete, and unclear. }\end{array}$ & $\begin{array}{l}\text { Students can draw pictures, } \\
\text { diagrams, graphs, or tables, } \\
\text { although unclear or } \\
\text { without explanation. }\end{array}$ & $\begin{array}{c}\text { Students can make a } \\
\text { mathematical model and solve } \\
\text { mathematical language } \\
\text { ((symbols, terms, signs, or } \\
\text { formulas) using an incorrect } \\
\text { calculation. }\end{array}$ \\
\hline $\begin{array}{c}3 \\
\text { High }\end{array}$ & $\begin{array}{l}\text { Students write } \\
\text { explanations using their } \\
\text { language correctly and } \\
\text { clearly, but not } \\
\text { completely. }\end{array}$ & $\begin{array}{l}\text { Students can draw pictures, } \\
\text { diagrams, graphs, or tables } \\
\text { clearly, but accompanied } \\
\text { by incorrect explanations. }\end{array}$ & $\begin{array}{l}\text { Students can make } \\
\text { mathematical models and } \\
\text { solve problems using } \\
\text { mathematical language } \\
\text { (symbols, terms, signs, or } \\
\text { formulas) incompletely }\end{array}$ \\
\hline $\begin{array}{c}4 \\
\text { Excellent }\end{array}$ & $\begin{array}{l}\text { Students write } \\
\text { explanations using their } \\
\text { language correctly, } \\
\text { clearly, and completely }\end{array}$ & $\begin{array}{c}\text { Students can describe } \\
\text { pictures, diagrams, graphs, } \\
\text { or tables clearly and } \\
\text { correctly }\end{array}$ & $\begin{array}{l}\text { Students can make } \\
\text { mathematical models and } \\
\text { solve problems using } \\
\text { mathematical language } \\
\text { (symbols, terms, signs, or } \\
\text { formulas) correctly and } \\
\text { completely }\end{array}$ \\
\hline
\end{tabular}

\section{The Results of the Research and the Discussion}

\section{A. Research Results}

Based on the research results conducted in class XI IPA 1, which amounted to 10 students, the following data were obtained thinking styles.

Table 3. Data on Students' Thinking Styles

\begin{tabular}{ccc} 
Thinking Styles & Students' Code & Number of Students \\
\hline Concrete Sequential & S1, S2, S3, S4, S5, S6 & 6 \\
\hline Abstract Sequential & S7, S8, S9, S10 & 4 \\
\hline
\end{tabular}

Based on Table 3, the comparison of concrete sequential and abstract sequential was 2: 3 . This indicated that the students had more concrete sequential thinking styles than abstract sequential thinking types. A mathematical communication skill test was conducted on four 
research subjects, namely two students with concrete sequential thinking style type and two students with abstract sequential thinking style.

\section{The Mathematical Communication Skills of Students' with Concrete Sequential Thinking Styles}

The following are the subjects S1 and S2's answers on the written text indicator.

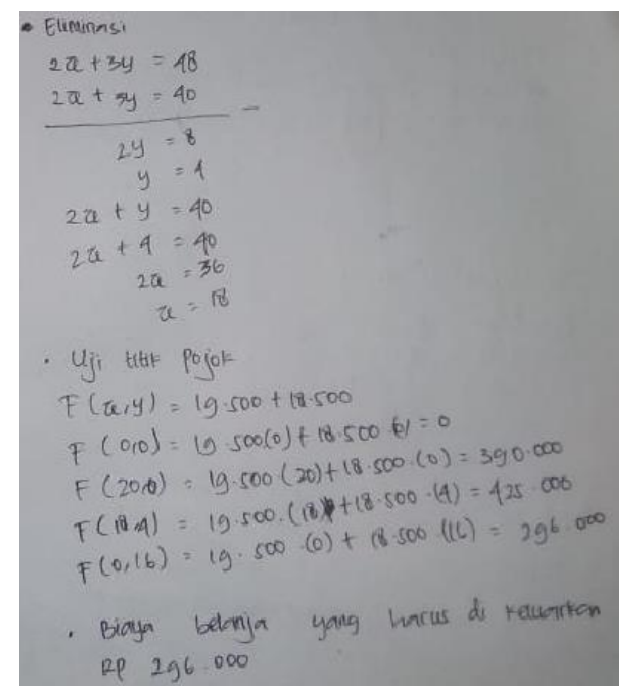

Figure 2. Subject S1's Answer on the Written Text Indicator

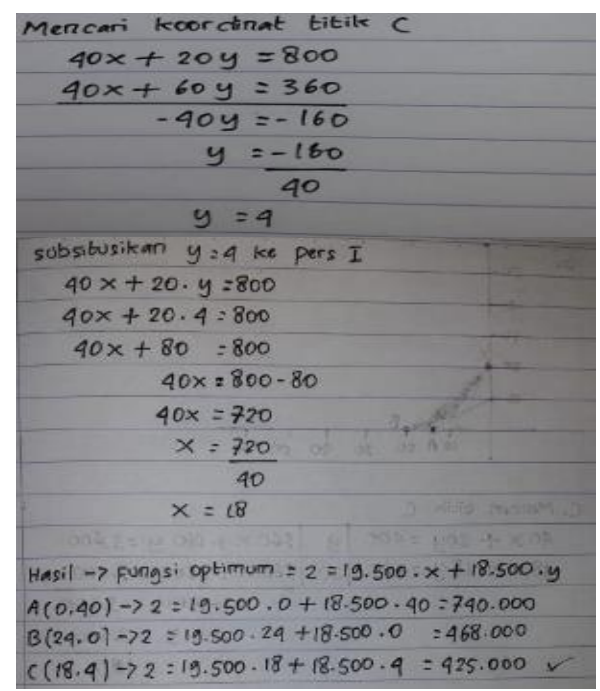

Figure 3. Subject S2's Answer on the Written Text Indicator

Based on Figure 2, subject S1 did not understand the questions, so that he did not answer the questions according to what was asked. Subject S1 answered the problem by finding the corner points then substituting them with the objective function. Subject S1 did not write down the $\mathrm{x}$ and $\mathrm{y}$ variables in the objective function. He also incorrectly chose the corner points that must be substituted; thus, the answer was wrong. Figure 3 shows the same thing as subject S1; subject S2 did not answer the problem by describing how to find the minimum cost. He also incorrectly substituted the corner points into the objective function by choosing the smallest cost. From the two answers, it was found that students with concrete sequential thinking style misunderstood the questions and unable to write entirely correct answers using their language.

The following are the subjects S1 and S2's answers on the drawing indicator.

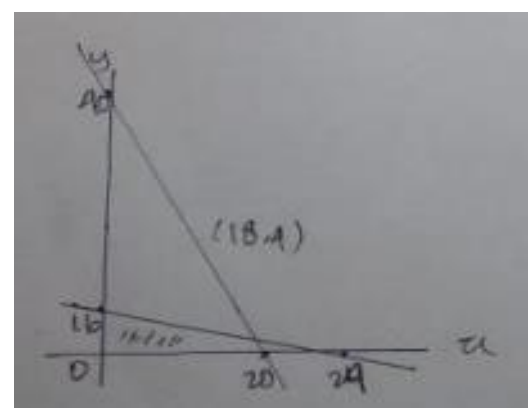

Figure 4. Subject S1's Answer on the Drawing Indicator

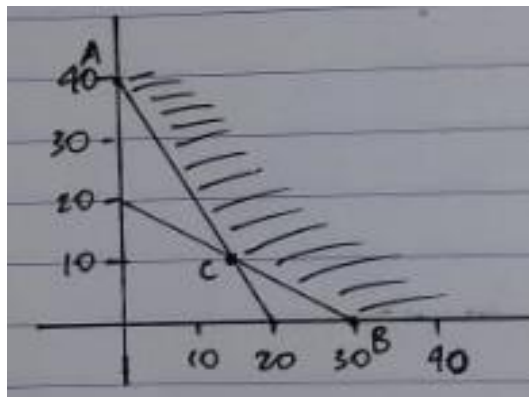

Figure 5. Subject S2's Answer on the Drawing Indicator

Based on Figure 4, subject S1 could make a graph, although he incorrectly determined the shading area following the predetermined model. Subject S1 did not write down how to find the coordinate points. Figure 5 shows that subject $\mathrm{S} 2$ could render graphic images and 
determine the shading area, but only partly correct. Subject S2 was wrong in determining the coordinate points according to the predetermined model and did not write down how to find the coordinate points to make the graph. From the answers obtained, the students could draw a picture, although but partly correct and incomplete.

Here are the subjects S1 and S2's answers on mathematical expression indicators.

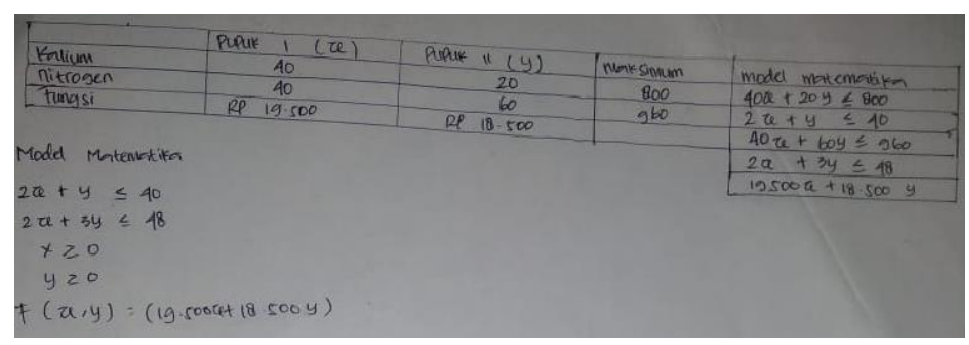

Figure 6. Subject S1's Answer on the Mathematical Expression Indicators

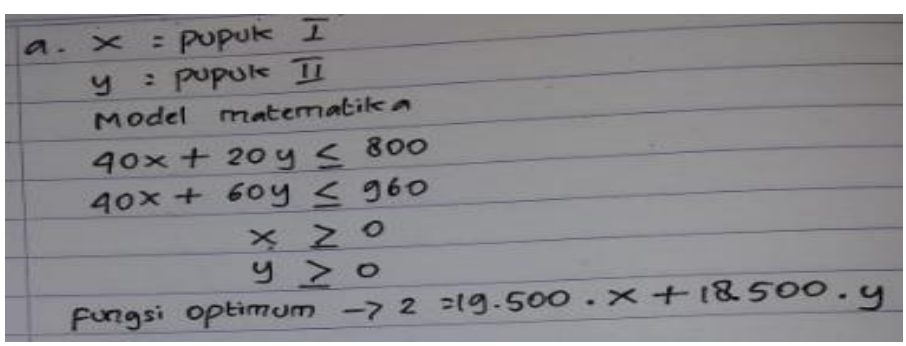

Figure 7. Subject S2's Answer on the Mathematical Expression Indicators

Figures 6 and 7 show that subjects S1 and S2 could make mathematical models of the problems presented, but there were several errors in determining the sign of inequality. The errors might be because they only understood some of the problem's information, so they could not make mathematical models correctly.

2. The Mathematical Communication Skills of Students with Abstract Sequential Thinking Style

The following are the subjects S7 and S8's answers on the written text indicator.

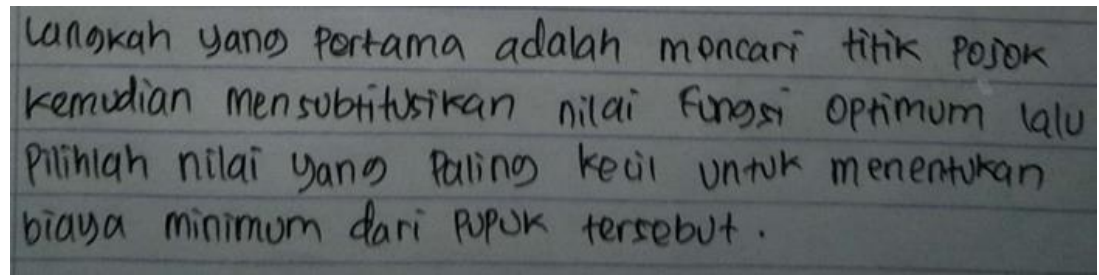

Figure 8. Subject S7's Answer on the Written Text Indicator

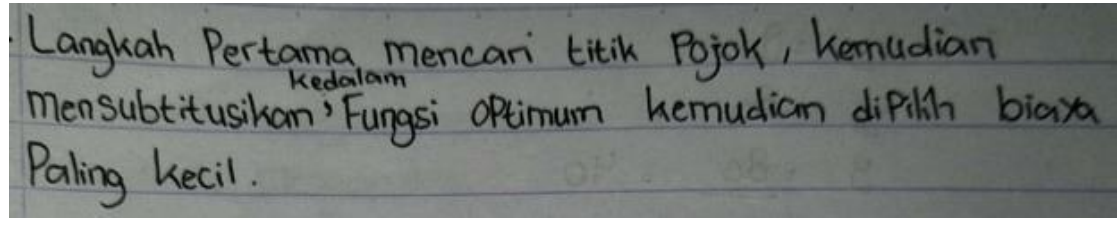

Figure 9. Subject S8's Answer on the Written Text Indicator 
Figures 8 and 9 show that subjects S7 and S8 could write several steps in their language, although incomplete and unclear. It can be seen from the two students' answers where they did not write down the steps to find the intersection point of known inequalities and did not clearly write down what was substituted into the objective function.

Here are the subjects S7 and S8's answers on the drawing indicator.

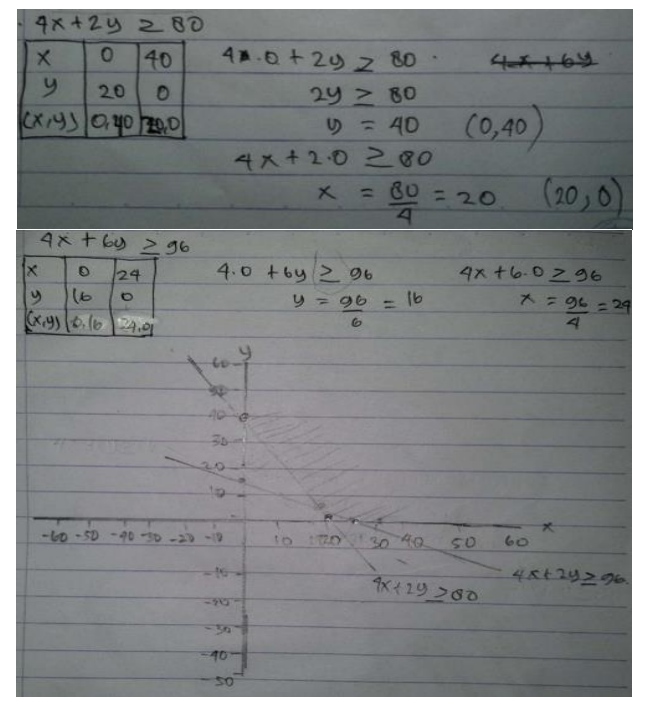

Figure 10. Subject S7's Answer on the Drawing Indicator
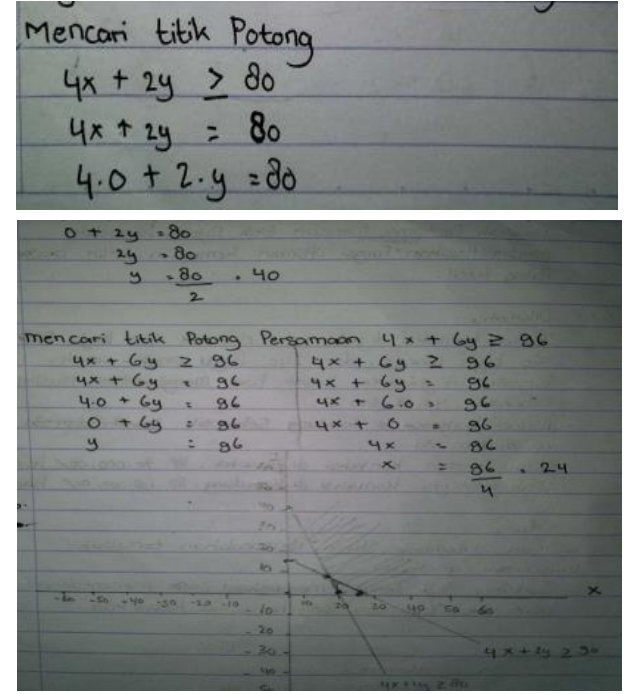

Figure 11. Subject S8's Answer on the Drawing Indicator

Figure 10 shows that subject S7 could make graphic images wholly and correctly. It can be seen in the answers where he wrote how to determine the coordinate points of the known inequalities. Then, he entered the coordinate points into the graphic image and determined the shading area correctly. Figure 11 shows that subject S8 could draw a graph and determine the shaded area correctly, although the coordinate points were incomplete.

Here are the subjects S7 and S8's answers on mathematical expressions indicators.

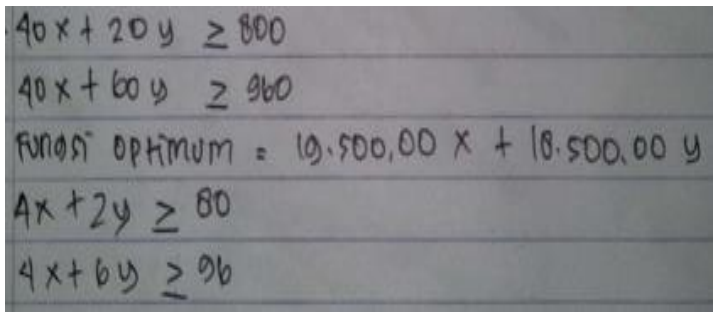

Figure 12. Subject S7's Answer on the Mathematical Expression Indicators

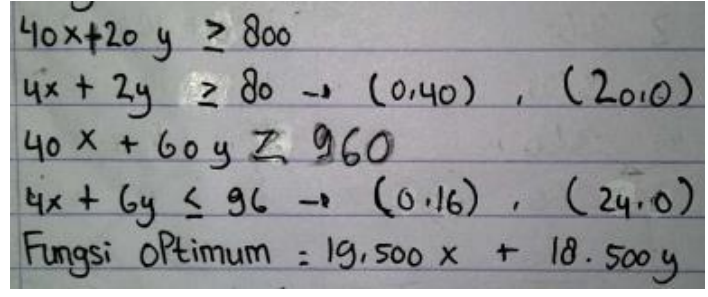

Figure 13. Subject S8's Answer on the Mathematical Expression Indicators

Figure 12 shows that subject S7 could make a mathematical model of the problem correctly but incompletely. Subject S7 did not write the conditions for $\mathrm{x}$ and $\mathrm{y}$ in the mathematical model. Figure 13 shows that subject S8's answer was less careful in writing the inequality sign to the mathematical model.

\section{B. Discussion}

Based on the research results, it was known that there were differences in students' mathematical communication skills in terms of their thinking styles. In the written aspect, students with concrete sequential thinking style cannot understand the problem well but can 
produce something concrete. Some concept errors made by students with concrete sequential thinking styles resulted in their inability to develop ideas. The students tended only to accept information or material provided by the teacher, and they were uninterested in exploring something abstract. The results were in line with Nurmitasari's research, which states that conceptual errors often obstacles students with concrete sequential thinking styles (Nurmitasari \& Astuti, 2019). Meanwhile, students with abstract sequential thinking styles can understand problems appropriately and write down abstract ideas using their language with good reasoning, although unclear. The results were also consistent with research conducted by Rahmy, which states that students with abstract sequential thinking style have difficulty understanding mathematics presentations and making arguments using their language (Rahmy et al., 2019).

Students with a concrete sequential thinking style can make graphs in the drawing aspect, although incomplete and partly correct. They tend to absorb information as it is. Students with abstract sequential thinking styles can draw graphs wholly and correctly because they can absorb lessons and information. Isyrofinnisak states that students with an abstract sequential thinking style understand concepts and analysis in understanding the material. Good mastery of material affects the students' success in determining solutions and transforming problems into images (Isyrofinnisak, 2020).

Students with concrete sequential thinking tend to need direction in absorbing information in the mathematical expression aspect. They tend to be wrong in determining the appropriate symbol to describe a problem. Nurmitasari found that students with a concrete sequential thinking style often make mistakes in symbols mathematical operations. They cannot continue the next operation to completely solve the problem (Nurmitasari \& Astuti, 2019). Students with an abstract sequential thinking style can make mathematical models correctly but incompletely because abstract sequential thinking can use and analyze information appropriately. Masruroh's research shows that students with an abstract sequential thinking style have a high academic level because of their logical, mathematical, and rational thought processes to solve mathematical problems (Masruroh, 2018) quickly.

Based on the explanation, it was found that students with a concrete sequential thinking style only fulfilled one indicator of mathematical communication skills, namely, stating a mathematical situation or idea in the form of pictures, graphs, tables, or diagrams. Meanwhile, students with an abstract sequential thinking style could fulfill two indicators of mathematical communication skills, namely expressing a mathematical situation or idea in the form of pictures, graphs, tables, or diagrams and expressing a mathematical situation or idea in the form of a mathematical symbol or model and solving it.

The novelty of this study lies in the measurement of mathematical communication skills. This study found that students' mathematical communication skills with an abstract sequential thinking style tended to be better than students with a concrete sequential thinking style on linear programming material. This result contradicts the results of research by Rahmy where students with a concrete sequential thinking style were better on straight line equation material. Students with a concrete sequential thinking style were better at exploring ideas and formulating generalizations than students with an abstract sequential thinking style (Rahmy et al., 2019). Another study by Depary shows that the physics learning outcomes of students with a concrete sequential thinking style are higher than students with an abstract sequential thinking style (Depary \& Mukhtar, 2013). 


\section{Conclusion and Suggestion}

Based on the research results, students with an abstract sequential thinking style tended to be better than students with a concrete sequential thinking style in terms of mathematical communication skills. Students with an abstract sequential thinking style could make generalizations based on good reasoning in the written text aspect. However, students with a concrete sequential thinking style tended to lack in making abstract guesses. In the drawing aspect, students with an abstract sequential thinking style had a good understanding of theories and concepts to draw graphics well. On the other hand, students with a concrete sequential thinking style could only apply some of the information received to draw graphs. In mathematical expressions, students with an abstract sequential thinking style could process the information implied in the problem to make mathematical models correctly. Meanwhile, students with a concrete sequential thinking style needed some additional information or direction to understand the information to avoid errors in making mathematical models.

Based on the results of the research and several field findings, the researchers suggest further researchers examine in-depth the four Gregorc thinking styles, investigate the factors affecting students' mathematical communication skills, conduct other reviews to determine students' mathematical communication skills, and conduct research on other materials or subjects with a larger population.

\section{References}

AlGhraibeh, A. M. A. (2015). Learning and Thinking Styles Based on Whole Brain Theory in Relation to Emotional Intelligence. Open Access Library Journal, 2(5).

Alifiyah, Y. R., \& Kurniasari, I. (2019). Identifikasi Tingkat Berpikir Kreatif Siswa dalam Memecahkan Masalah Open Ended Ditinjau dari Gaya Berpikir Sternberg. MATHEdunesa, 8(2), 216-222.

Azizah, S. N., \& Maulana, D. F. (2018). Analisis Kemampuan Komunikasi Matematis Pada Siswa SMA. Prosiding Seminar Nasional Matematika dan Pendidikan Matematika (SNMPM), 2(1), 222-228.

Depary, S., \& Mukhtar. (2013). Model Pembelajaran dan Gaya Berpikir Terhadap Hasil Belajar Fisika. Jurnal Teknologi Pendidikan, 6(1), 93-107.

Deporter, B., \& Hernacki, M. (2015). Quantum Learning:Membiasakan Belajar Nyaman dan Menyenangkan. Bandung: Kaifa.

Djadir, H. U., \& Sulfianti, A. (2018). The Profile of Students ' Mathematical Problem Solving on the Topic of Two-Variable Linear Equation Systems Based on Thinking Styles. Journal of Physics: Conference Series, 1028(1).

Firdaus, A., Nisa, L. C., \& Nadhifah. (2019). Kemampuan Berpikir Kritis Siswa pada Materi Barisan dan Deret Berdasarkan Gaya Berpikir. Kreano: Jurnal Matematika KreatifInovatif, 10(1), 68-77.

Isyrofinnisak, F. (2020). Analisis Kreativitas Matematis dan Komunikasi Matematis Ditinjau dari Gaya Berpikir Siswa Kelas VIII MTsN 1 Kediri Tahun Ajaran 2019/2020. Universitas Sebelas Maret.

Khair, M. S., Subanji, \& Muksar, M. (2018). Kesalahan Konsep dan Prosedur Siswa dalam 
Menyelesaikan Soal Persamaan Ditinjau dari Gaya Berpikir. Jurnal Pendidikan: Teori, Penelitian, dan Pengembangan, 3(5), 620-633.

Khambali, Rasyid, Y., \& Rafli, Z. (2019). Pengaruh Model Pembelajaran Kooperatif dan Gaya Berpikir Terhadap Hasil Belajar Qiro'ah. Dirasat: Jurnal Studi Islam \& Peradaban, 14(1).

Lenterawati, B. S., Pramudya, I., \& Kuswardi, Y. (2018). Analisis Kesalahan Berdasarkan Tahapan Kastolan dalam Menyelesaikan Soal Cerita Sistem Persamaan Linear Dua Variabel Ditinjau dari Gaya Berpikir Siswa Kelas VIII SMP Negeri 19 Surakarta Tahun Pelajaran 2018/2019. SOLUSI, 2(6), 471-482.

Masruroh, H. L. (2018). Analisis Berpikir Relasional Siswa dengan Gaya Berpikir Sekuensial Abstrak dalam Menyelesaikan Masalah Matematika. UIN Sunan Ampel Surabaya.

Moleong, L. J. (2014). Metodelogi Penelitian Kualitatif. Bandung: PT. Remaja Rosdakarya.

Muflihah, I. S., Ratnaningsih, N., \& Apiati, V. (2019). Analisis Kemampuan Koneksi Matematis Ditinjau dari Gaya Berpikir Peserta Didik. Journal Authentic Research on Mathematics Education (JARME), 1(1), 68-77.

Munahefi, D. N., Kartono, Waluya, B., \& Dwijanto. (2020). Kemampuan Berpikir Kreatif Matematis pada Tiap Gaya berpikir Gregorc. PRISMA: Prosiding Seminar Nasional Matematika, 3, 650-659.

Nurmitasari, \& Astuti, R. (2019). Students ' Learning Obstacles on Generating Function Reviewed from The Characteristics of Thinking. Journal of Physics: Conference Series, 1155.

Oktari, D., \& Haji, S. (2018). Meningkatkan Kemampuan Komunikasi Matematis Mahasiswa S1 PGMI dengan Pembelajaran Investigasi pada Matakuliah Metodologi Penelitian Di IAIN Kota Bengkulu. Jurnal Equation, 1(1), 95-110.

Rahmawati, F. (2018). Pengaruh Model Group Investigation Terhadap Kemampuan Komunikasi Matematis Siswa Kelas V SD. Terampil: Jurnal Pendidikan dan Pembelajaran Dasar, 5(2), 198-205.

Rahmawati, N. S., Bernard, M., \& Akbar, P. (2019). Analisis Kemampuan Komunikasi Matematik Siswa SMK Pada Materi Sistem Persamaan Linier Dua Variabel (SPLDV). Journal on Education, 1(2), 344-352.

Rahmy, S. N., Usodo, B., \& Slamet, I. (2019). Mathematics Communication Skill of Student in Junior High School Based on Students Thinking Style. Journal of Physics: Conference Series PAPER, 1188(1).

Safa'udin, M., Budiyono, \& Saputro, D. R. S. (2015). Eksperimentasi Model Pembelajaran Problem Based Learning Dan Kooperatif Tipe Snowball Throwing Ditinjau Dari Gaya Belajar Siswa. Jurnal Elektronik Pembelajaran Matematika, 3(8), 858-867.

Sari, D. S., Kusnandi, K., \& Suhendra, S. (2017). A Cognitive Analysis of Students ' Mathematical Communication Ability on Geometry. Journal of Physics: Conference Series, 895(1).

Sumandya, I. W. (2018). Pengaruh Penerapan Pendekatan Pembelajaran RME (Realistic Mathematic Education) dan Gaya Berpikir Terhadap Hasil Belajar Matematika Siswa. Emasains, 7(1), 55-65. 
Veva, E. Y., Usodo, B., \& Pramesti, G. (2018). Penerapan Metode Pemecahan Masalah dengan Pendekatan Reciprocal Teaching untuk Meningkatkan Kemampuan Komunikasi Matematis dan Partisipasi Siswa Kelas VIII.I SMP Negeri 3 Karanganyar. SOLUSI, 2(6).

Zahri, M., Budayasa, I. K., \& Lukito, A. (2019). Written Mathematical Communication Accuracy on Linear Equation and Inequality. Journal of Physics: Conference Series, $1188(1)$. 